\title{
Awareness of Oral Cancer in a Northwestern Nigerian State: Assessing the Knowledge, Opinion, and Practice of Traditional Healers and Herbalists
}

\author{
Rafael A. Adebola, ${ }^{1,2}$ Babatunde O. Bamgbose, ${ }^{3}$ Joshua B. Adeoye, ${ }^{2}$ and Taiwo G. Amole ${ }^{4}$ \\ ${ }^{1}$ Oral and Maxillofacial Surgery Department, Aminu Kano Teaching Hospital, Kano 23400, Nigeria \\ ${ }^{2}$ Preventive Dentistry Department, Bayero University, Kano 23400, Nigeria \\ ${ }^{3}$ Oral Diagnostic Sciences Department, Faculty of Dentistry, Bayero University, Kano 23400, Nigeria \\ ${ }^{4}$ Community Health Department, Bayero University, Kano 23400, Nigeria \\ Correspondence should be addressed to Rafael A. Adebola; aderafel@yahoo.co.uk
}

Received 17 September 2013; Revised 29 November 2013; Accepted 1 December 2013

Academic Editor: Shun-Fa Yang

Copyright (C) 2013 Rafael A. Adebola et al. This is an open access article distributed under the Creative Commons Attribution License, which permits unrestricted use, distribution, and reproduction in any medium, provided the original work is properly cited.

\begin{abstract}
Background: Traditional healers/herbalists remain one of the most accessible and popular options of care to people suffering from cancers particularly at the community level in Nigeria. The majority of patients with oral cancer present at the terminal stage after exploring unorthodox care. This study assesses the awareness of oral cancer among traditional caregivers in Kano State, Northwestern (NW) Nigeria. Methods: Self-administered, structured questionnaires were administered to a cross section of 21 traditional caregivers. Results: Of the 21 traditional caregivers studied, the majority (66.7\%) had never heard of oral cancer and only 7 (33.3\%) were aware. The level of knowledge on oral cancer was assessed using a scoring system classifying respondents as having adequate $(>50 \%)$ or inadequate $(<50 \%)$ knowledge. There was a significant educational status gap as respondents with informal education had lesser knowledge than that of their counterparts who had formal education (61.9\% versus $19.0 \%)(P=0.012)$. Conclusions: It is important to have allied healthcare providers informed about oral cancer, as their knowledge and awareness of oral cancer and its risk factors, which were low in our study, are vital in prevention and early detection. Impact: This study provides an insight into oral cancer prevention using traditional herbalists who are popular caregivers for those seeking health-related solutions.
\end{abstract}

\section{Introduction}

Oral cancer (squamous cell carcinoma) constitutes over ninety percent $(90 \%)$ of malignancies affecting the oral and maxillofacial region [1]. The incidence is increasing, with most cases occurring in the fifth to seventh decades of life-probably because of long exposure to tobacco and alcohol, oftentimes with underlying poor nutrition, which is a prerequisite for malignant transformation $[1,2]$. Patients generally present at a late stage when the prognosis is poor [2$4]$. The population at risk of oral cancer includes those aged over 65 years, chronic alcohol and tobacco users, and black males [5].

In the United States, oral cancer represents less than thirty percent $(30 \%)$ of all cancers but has one of the lowest fiveyear survival rates among major cancers, including breast, prostate, and colon cancers [6]. It is estimated that thirty thousand $(30,000)$ new cases are diagnosed yearly and about eight thousand (8000) will die of the disease [6].

Carcinoma of the oral cavity occurring in Africans is poorly documented [7], and most studies carried out are prevalence studies without statistics on survival rates [7-22]. Although oral cancer is considered rare in Africa [7], studies held in East Africa [8-10] and in major maxillofacial surgery centers in Kaduna [7], Ibadan [11-15], Lagos [16-18], Enugu [19], and Maiduguri [20-22] in Nigeria, West Africa, suggest that it may occur more frequently than has been documented.

Nigerians have been noted to consume alcohol the most in Africa, second only to South Africans [23]. The increasing consumption of alcohol and tobacco within the country [24] further poses an increased risk to the population at risk of oral 
cancer. In the predominantly Islamic northwestern region with bans on alcohol use that largely limit availability [25], reports on consumption rates remain very high [26].

Tobacco consumption in ways pertinent to oral cancer (cigarette smoking, pipe smoking, and chewing tobacco) is reported to be lower than alcohol usage on the other hand [27], although the proportion of adults above 15 years of age who consume these products is said to be rising rapidly [27, 28].

Actinic radiation, due to exposure to sunlight, is also known to predispose to lip carcinomas [29]. Kano, NW Nigeria, is a semiarid state located in the Sudan savannah belt of Africa, almost abutting the Sahara Desert on longitude and latitude $12^{\circ} 0^{\prime} 0^{\prime \prime} \mathrm{N}, 8^{\circ} 31^{\prime} 0^{\prime \prime}$, receiving between 8 to 10 hours of sunshine daily [30].

People in the region may be at a higher risk of developing oral carcinoma, whether their daily jobs are outdoors or not, though this is bated by the protection conferred by the dark skin [29] of most individuals in the region.

The five-year survival rate of oral cancer directly correlates with the stage of the disease at presentation or diagnosis [5]. It ranges from eighty percent (80\%) for cases diagnosed at localized stages to less than thirty percent (30\%) for cases that have metastasized to other sites [31]. Early detection and treatment, thus, remain vital to surviving oral cancer $[1,32]$.

A viable alternative for early detection via screening modalities could be the use of other health caregivers in the region, including pharmacists, chemists, nurses, and traditional healers, who are frequently patronized by a large proportion of the population. This is because there is gross inadequacy of dental personnel in Kano State as the Maxillofacial Surgery Center-with its five oral and maxillofacial surgeons and twenty (20) resident doctors-serves the entire state with an estimated population of 12 million [33, 34] and receives referral cases from other states in Northwestern (NW) Nigeria. Kano State has a total of fifty (50) dentists in its population and this limits the effectiveness of screening modalities for early cancer detection.

The culture of the indigenous population, though compounded at times by poor accessibility to healthcare facilities, largely influences the people's healthcare-seeking behavior. Traditional healers and herbalists are an integral part of the culture around parts of Africa and Nigeria [35, 36].

When members of the community develop oral pathologies, it is the norm to seek care from these traditional healers and herbalists, referred to as "Boka," and this is more likely than visiting a dentist or physician. This could be due to the paucity of orthodox healthcare practitioners practicing in NW Nigeria or poor knowledge and attitude of the populace related to dental needs and access to dental care.

Commuting to the city center from remote villages is also often a challenge, making these traditional healers and herbalists the most likely to be contacted when people have medical problems or symptoms. These traditional healers and herbalists live among the people and are thus more easily accessible and available. These and other factors make the traditional healers and herbalists very popular in NW Nigeria in particular.
Understanding the awareness of oral cancer among traditional healers and herbalists in Kano State, NW Nigeria, could be a first step to formulating strategies to improve early detection and treatment of oral cancer, especially since reports in the literature suggest that regardless of the time of diagnosis blacks appear to have a worse prognosis than whites [31, 37-40].

This study sought to assess the awareness of oral cancer among a group of traditional healers and herbalists in Kano State, NW Nigeria. The knowledge, opinion, and practice of traditional healthcare providers who serve as the closest and first point of call to many are essential to planning a training program for oral cancer detection.

\section{Methods}

2.1. Study Design and Population. The study was descriptive and cross-sectional in design. It was a questionnaire-based statewide study carried out to assess oral cancer awareness of traditional healthcare providers in Kano State, NW Nigeria. There was no central registry of traditional healers and herbalists in the state and, thus the authors did not know their addresses. Members of staff and patients of the Aminu Kano Teaching Hospital Dental and Maxillofacial Center, who are indigenes of the state and are familiar with the rural communities, were interviewed to provide clues in respect of the locations of the traditional healers and herbalists. This yielded a working list of thirty-three (33) traditional healers and herbalists with their addresses and was used as the sampling frame.

2.2. Instrument Description/Data Collection. The self-administered questionnaire was prepared in English and translated to Hausa language, as Hausa is the predominant language in Northern Nigeria. To ensure a verifiable standard, an independent, trained translator was recruited to translate the self-administered questionnaire from Hausa language back into English language, and this second English questionnaire was compared for similarity with the first. This was done to validate the Hausa questionnaire.

Two members of staff of the Maxillofacial Surgery Center delivered the questionnaires to identified traditional healers and herbalists, who filled out the document and handed them back to the dispatch staff.

The structured self-administered questionnaire was adapted from that used in a previous study and had four sections. The first section inquired about the sociodemographic characteristics of the respondents including age, gender, marital status, level of education, and ethnicity. The second part elicited information about awareness, the third sought information about risk factors, signs, and symptoms of oral cancer, and the fourth part assessed respondents' perception and practice as regards suspected cancer cases.

2.3. Data Analysis. Data was collated and processed using Microsoft Excel and IBM SPSS for Mac 2011. Quantitative variables were summarized using the mean and standard deviation while categorical variables were summarized as frequencies and percentages. 
The level of knowledge of oral cancer was assessed among the respondents and each correctly answered question earned one mark giving a maximum score of 25 on "knowledge." Scores $0-12(<50 \%)$ were graded as inadequate knowledge on oral cancer while 13 and above $(>50 \%)$ were graded as adequate knowledge on oral cancer. Perception was also assessed using knowledge- and practice-related opinion questions.

\section{Results}

3.1. Sociodemographic Characteristics. Thirty-three (33) traditional healers and herbalists constituted the study population. Of these, twenty-one (21) responded to the questionnaire; eight (8) desisted from answering; one (1) could not be located; and three (3) were away on business or family matters. Response rate was thus $63.63 \%$.

The age of respondents ranged from 37 to 72 years with a mean of $49.4 \pm 9.8$ years. Table 1 shows the sociodemographic characteristics of the respondents. Almost all were male (95\%), and the majority were married and of the Hausa ethnic group ( $86 \%$ and $81 \%$, resp.). Of the non-Hausas (19\%), two were non-Nigerian and the other two were from northern minority tribes. Quranic education (Islamic education received by Muslims from imams and mullahs, lecturers of the Koran, that commonly takes place before and concurrently with, but independently of, formal education [41-43]) was the preponderant educational qualification (61.9\%).

3.2. Knowledge. Only 7 (33\%) respondents had ever heard of oral cancer. Respondents' knowledge of risk factors, signs, and symptoms was assessed among the 7 respondents who were aware (Tables 2 and 3). Overall, the knowledge level on oral cancer was considered adequate in $4(19.0 \%)$ of the respondents.

None of the socio-demographic characteristics of the traditional caregivers except educational status was significantly associated with their level of knowledge of oral cancer.

None of the respondents who had only Quranic knowledge had adequate knowledge of oral cancer. The four respondents who had adequate knowledge of oral cancer had at least secondary education. This difference in level of knowledge and formal education was statistically significant (Fisher's exact test $=0.01$ ) (Table 5).

Respondents were asked questions on "real" risk factors and "non-real" risk factors. "Real" risk factors constituted those proven by research and include excessive exposure to sunlight, regular alcohol consumption, tobacco use, poor nutrition (vegetables and fruits), previous oral cancer lesions, older age, and occupational hazard [44].

Regular consumption of alcohol and tobacco use were the most identified as risk factors (28.6\%) while age was not mentioned by any of the respondents as a risk factor. Of the seven respondents who had heard of oral cancer before, almost all (86\%) correctly identified smoking and tobacco as risk factors. The values were much less for other "real" risk factors as follows: sunlight and poor nutrition (vegetables and fruits) (9.5\%), previous oral cancer lesions (19.0\%), older age (0\%), and occupational hazard (19.0\%).
TABLE 1: Sociodemographic chracteristics of respondents.

\begin{tabular}{|c|c|c|}
\hline Characteristic & Frequency $(n=21)$ & Percentage (\%) \\
\hline \multicolumn{3}{|l|}{ Age group (years) } \\
\hline $30-39$ & 3 & 14.3 \\
\hline $40-49$ & 9 & 42.9 \\
\hline $50-59$ & 6 & 28.6 \\
\hline 60 and above & 3 & 14.3 \\
\hline \multicolumn{3}{|l|}{ Gender } \\
\hline Male & 20 & 95.2 \\
\hline Female & 1 & 4.8 \\
\hline \multicolumn{3}{|l|}{ Marital status } \\
\hline Married & 18 & 85.7 \\
\hline Single & 1 & 4.8 \\
\hline Divorced & 1 & 4.8 \\
\hline Widowed & 1 & 4.8 \\
\hline \multicolumn{3}{|c|}{ Educational qualification } \\
\hline Quranic & 13 & 61.9 \\
\hline Primary & - & - \\
\hline Secondary & 6 & 28.6 \\
\hline Tertiary & 2 & 9.5 \\
\hline \multicolumn{3}{|l|}{ Ethnicity } \\
\hline Hausa & 17 & 81.0 \\
\hline Others & 4 & 19.0 \\
\hline \multicolumn{3}{|l|}{ Nationality } \\
\hline Nigerian & 19 & 90.5 \\
\hline Non-Nigerian & 2 & 9.5 \\
\hline
\end{tabular}

TABLE 2: Awareness of oral cancer.

\begin{tabular}{lcc}
\hline Ever heard of oral cancer & Frequency $(n=21)$ & Percentage (\%) \\
\hline Yes & 7 & 33.3 \\
No & 14 & 66.7 \\
\hline
\end{tabular}

TABLE 3: Awareness of oral cancer examinations.

\begin{tabular}{lcc}
\hline $\begin{array}{l}\text { Ever heard of oral cancer } \\
\text { examination? }\end{array}$ & Frequency $(n=21)$ & Percentage (\%) \\
\hline Yes & 0 & 0 \\
No & 21 & 100 \\
\hline
\end{tabular}

TABLE 4: Knowledge of oral cancer.

\begin{tabular}{lcc}
\hline Knowledge of oral cancer & Frequency & Percentage (\%) \\
\hline Adequate & 4 & 19.0 \\
Inadequate & 17 & 81.0 \\
\hline
\end{tabular}

"Non-real" risk factors are those without supporting research evidence but "common-sense" and popular belief identify as leading to oral cancer. They do not, in actual fact, cause oral cancer. These were eating hot, spicy foods; frequent biting of the cheek or lip; dirty mouth; poorly fitting dentures; family history; and spiritual/demonic attack [44].

For the "non-real" risk factors, values were as follows: eating hot and spicy food, frequent biting of the cheek or lip, poorly fitting dentures, and previous family history (4.8\%) 
TABLE 5: Factors associated with respondents' knowledge of oral cancer.

\begin{tabular}{|c|c|c|c|c|}
\hline Sociodemographic characteristic & Adequate $n(\%)$ & Inadequate $n(\%)$ & Total & $P$ value \\
\hline \multicolumn{5}{|l|}{ Age group (years) } \\
\hline$<50$ & $3(25.0)$ & $9(75.0)$ & $12(100)$ & \multirow{3}{*}{0.6} \\
\hline$\geq 50$ & $1(11.1)$ & $8(88.9)$ & $9(100)$ & \\
\hline Total & $4(19.0)$ & $17(81.0)$ & $21(100)$ & \\
\hline \multicolumn{5}{|l|}{ Gender } \\
\hline Male & $4(20.0)$ & $16(80.0)$ & $20(100)$ & \multirow{3}{*}{1.0} \\
\hline Female & $0(0)$ & $1(100)$ & $1(100)$ & \\
\hline Total & $4(19.0)$ & $17(81.0)$ & $21(100)$ & \\
\hline \multicolumn{5}{|l|}{ Marital status } \\
\hline Married & $2(11.1)$ & $16(88.9)$ & $18(100)$ & \multirow{3}{*}{0.08} \\
\hline Not married & $2(66.7)$ & $1(33.3)$ & $3(100)$ & \\
\hline Total & $4(19.0)$ & $17(81.0)$ & $21(100)$ & \\
\hline \multicolumn{5}{|l|}{ Educational qualification } \\
\hline Formal & $4(50.0)$ & $4(50.0)$ & $8(100)$ & \multirow{3}{*}{$0.012^{*}$} \\
\hline Informal & $0(0)$ & $13(100)$ & $13(100)$ & \\
\hline Total & $4(19.0)$ & $17(81.0)$ & $21(100)$ & \\
\hline \multicolumn{5}{|l|}{ Ethnicity } \\
\hline Hausa/Fulani & $4(23.5)$ & $13(76.5)$ & $17(100)$ & \multirow{3}{*}{0.5} \\
\hline Others & $0(0)$ & $4(100)$ & $4(100)$ & \\
\hline Total & $4(19.0)$ & $17(81.0)$ & $21(100)$ & \\
\hline \multicolumn{5}{|l|}{ Nationality } \\
\hline Nigerian & $4(21.1)$ & $15(78.9)$ & $19(100)$ & \multirow{3}{*}{1.0} \\
\hline Non-Nigerian & $0(0)$ & $2(100)$ & $2(100)$ & \\
\hline Total & $4(19.0)$ & $17(81.0)$ & $21(100)$ & \\
\hline
\end{tabular}

* Statistically significant.

Fishers exact test was used to calculate $P$-values.

TABLE 6: Respondents' knowledge of risk factors of oral cancer.

\begin{tabular}{|c|c|c|c|}
\hline \multirow{2}{*}{ Risk factor } & \multicolumn{3}{|c|}{ Frequency (\%) } \\
\hline & Yes & No & Total \\
\hline Excessive exposure to sunlight & $2(9.5)$ & $19(90.5)$ & $21(100)$ \\
\hline Eating hot, spicy foods & $1(4.8)$ & $20(95.2)$ & $21(100)$ \\
\hline Regular consumption of alcohol & $6(28.6)$ & $15(71.4)$ & $21(100)$ \\
\hline Tobacco use & $6(28.6)$ & $15(71.4)$ & $21(100)$ \\
\hline Frequent biting of the cheek or lip & $1(4.8)$ & $20(95.2)$ & $21(100)$ \\
\hline Poor nutrition (lack of vegetables and fruits) & $2(9.5)$ & $19(90.5)$ & $21(100)$ \\
\hline Previous oral cancer lesions & $4(19.0)$ & $17(81.0)$ & $21(100)$ \\
\hline Old people & $0(0)$ & $21(100)$ & $21(100)$ \\
\hline Dirty mouth & $3(14.3)$ & $18(85.7)$ & $21(100)$ \\
\hline Poorly fitting dentures & $1(4.8)$ & $20(95.2)$ & $21(100)$ \\
\hline Family history & $1(4.8)$ & $20(95.2)$ & $21(100)$ \\
\hline Occupational hazard & $4(19.0)$ & $17(81.0)$ & $21(100)$ \\
\hline Spiritual/demonic attack & $21(100)$ & $0(0)$ & $21(100)$ \\
\hline
\end{tabular}

and dirty mouth (14.3\%). Responses to risk factors are as shown in Table 6.

Questions were also asked on the signs and symptoms of oral cancer, including presence of a chronic nonhealing ulcer, a lump in the cheek that can be felt with the tongue, white or red patches on intraoral soft tissues, soreness in the throat, dysphagia or difficulty chewing, numbness of tongue or some other mouth parts, abnormal neck swelling, burning sensation in the mouth (dysgeusia), dry mouth, and bleeding from the gums.

Burning sensation was the most identified symptom (33.3\%), while soreness or a feeling of something being caught in the throat was the least identified (4.8\%). Respondents' knowledge of signs and symptoms is as shown in Table 7. 
TABLE 7: Respondents' knowledge of signs and symptoms of oral cancer.

\begin{tabular}{|c|c|c|c|}
\hline \multirow{2}{*}{ Sign/symptom } & \multicolumn{3}{|c|}{ Frequency (\%) } \\
\hline & Yes & No & Total \\
\hline A sore in the mouth that bleeds easily and does not heal & $6(28.6)$ & $15(71.4)$ & $21(100)$ \\
\hline A lump or thickening in the cheek that can be felt with the tongue & $6(28.6)$ & $15(71.4)$ & $21(100)$ \\
\hline A white or red patch on the gums, tongue, or lining of the mouth & $4(19.0)$ & $17(81.0)$ & $21(100)$ \\
\hline Soreness or a feeling that something is caught in the throat & $1(4.8)$ & $20(95.2)$ & $21(100)$ \\
\hline Difficulty chewing or swallowing & $2(9.5)$ & $19(90.5)$ & $21(100)$ \\
\hline Numbness of the tongue or other area of the mouth & $4(19.0)$ & $17(81.0)$ & $21(100)$ \\
\hline An abnormal swelling in the neck & $4(19.0)$ & $17(81.0)$ & $21(100)$ \\
\hline Burning sensation & $7(33.3)$ & $14(66.7)$ & $21(100)$ \\
\hline Loss of taste & $2(9.5)$ & $19(90.5)$ & $21(100)$ \\
\hline Dry mouth & $3(14.3)$ & $18(85.7)$ & $21(100)$ \\
\hline Bleeding from the gums & $3(14.3)$ & $18(85.7)$ & $21(100)$ \\
\hline
\end{tabular}

TABLE 8: Respondents' choice of patient referral.

\begin{tabular}{lcc}
\hline Choice of patient referral & Yes $n(\%)$ & No $n(\%)$ \\
\hline Doctor & $5(23.8)$ & $16(76.2)$ \\
Dentist & $12(57.1)$ & $9(42.9)$ \\
Buying products & $13(61.9)$ & $8(38.1)$ \\
Self-care & $17(81.0)$ & $4(19.0)$ \\
Rituals & $3(14.3)$ & $18(85.7)$ \\
\hline
\end{tabular}

Interestingly, all the 4 herbalists who had adequate knowledge of oral cancer correctly identified chronic alcohol usage, tobacco use, previous oral lesions, and occupational hazard/exposure as risk factors of developing oral cancer. Knowledge of other risk factors, including symptoms, was more equivocal.

3.3. Perception. Perception questions included knowledgerelated opinions, from which 4 (19\%) strongly agreed that early detection would improve the chances of successfully treating oral cancers. Unsurprisingly, these were those whose knowledge about oral cancer turned out as "adequate." These were also the only four who disagreed with the assertion that the development of cancer was a matter of chance and so nothing could be done to avoid it. Seventeen $(81.0 \%)$ of the respondents agreed with this.

Slightly more than half $(11(52 \%))$ thought that life changes could be made to reduce the risk of developing oral cancer, but all the respondents felt a spiritual or demonic attack could cause oral cancer. Finally, none of the respondents had ever heard of an oral cancer examination as indicated in Table 4.

When respondents were asked "How concerned are you about oral cancer?" only 11 (52.4\%) were "very" concerned, $6(28.6 \%)$ were "somewhat" concerned, and the remaining claimed not to be concerned. Sixteen $(76.2 \%)$ indicated that they would refer a patient with a mouth sore to a doctor, 12 (57.1\%) indicated a dentist, and 17 (81.0\%) indicated that they would attempt some "self-care." Only $3(14.3 \%)$ indicated that they would suggest some rituals (Table 8 ).

Only $12(57 \%)$ of the respondents desired some further information or teaching on oral cancer even though all but one of the respondents (95\%) felt their knowledge about prevention and detection of oral cancer was insufficient. Of those who wanted further information, the most frequently desired format of teaching was via information packs (50\%), as opposed to lectures (33\%) and seminars (17\%).

\section{Discussion}

The cultural nature of some African communities such as ours has allowed a deep influence of traditional caregivers on people's healthcare-seeking behavior. Many a times they are the first option of care and may remain the only option for some patients [35]. Their practice usually involves combination of healing techniques; some are visible such as the use of herbs, while others involving the use of spiritual or divine means are invisible. Many a times though, these traditional healers have no standards in their practice, albeit, they are highly respected and patronized.

The lopsided distribution of oral health professionals (dentist-patient ratio of $1: 260,000)$ might have also encouraged the patronage of traditional healers and herbalists by the people of the state. Although they are very popular, there is no central registry for traditional healers and herbalists practicing in the state. This was a limitation in this present study.

The level of the awareness about oral cancer (33.3\%) among traditional healers is abysmally low. Traditional healers are considered the first point of call when seeking for holistic healthcare in our setting and the low awareness about oral cancer may be partly responsible for late presentations as commonly seen in our clinics. Worse still, only 4 (19.0\%) of the traditional healers had knowledge of oral cancer.

With such low levels of awareness among traditional caregivers, patients would be badly managed and only present at the terminal stages of their disease. Late diagnoses have been attributed to the public's lack of knowledge about the risk factors and early signs of oral cancer $[45,46]$.

However, much higher levels of awareness (72\%) were reported among dental patients in a southwestern tertiary hospital in Nigeria [47] and a comparable level of awareness was noted in a population-based study in North Carolina [48] in the United States, where $86 \%$ of the respondents had heard of oral cancer and 56\% $(n=1096)$ had knowledge 
of the risk factors. The low level of awareness noted in our study may be connected to the fact that the sample size was small and the traditional healers being studied probably had lower educational qualifications, as awareness has been noted to be linked to educational status [47]; it is not surprising that educational qualification of the traditional healers and herbalists played a significant role in their level of knowledge of oral cancer $(P=0.012)$.

Our study supports a generally held notion that traditional healers regard themselves as knowledgeable in the understanding and treatment of diseases. This was typified by the choice of referral that most of the traditional healers would recommend for a patient with oral cancer. Most of them would prescribe care that would be given by them (81.0\%). Even though the majority of them (95.2\%) judged their knowledge as inadequate, a much lesser proportion (57.1\%) desired more information to be given to them on oral cancer.

The fact that all the traditional healers and herbalists enrolled in this study believed that spiritual or demonic attack is responsible for oral cancer is a clear reflection of the religious and cultural beliefs of our society. Culturally sensitive but scientific means of health-educating the traditional healers in different settings would have to be devised to overcome barriers of ignorance and the feeling of selfsufficiency in patient care. An untapped potential, however, may be integrating the practice of traditional healers into biomedical care, as traditional medicine remains culturally acceptable, available, and accessible to many Africans [35].

Such integration has been found to be useful in the comprehensive management of HIV/AIDS and other STIs particularly in rural settings where proximity to traditional healers prompted early referral to medical care [35].

In summary, building the capacity of traditional healers and herbalists by improving their knowledge and awareness of oral cancer and its risks factors would remain vital in the prevention and early detection of oral cancer. The importance of early detection and referral to equipped healthcare facilities for appropriate care must also be emphasized.

\section{Conflict of Interests}

The authors report no conflict of interests. The authors alone are responsible for the content and writing of the paper.

\section{Authors' Contribution}

Dr. Adebola was responsible for conception and design of the study, as well as study supervision; Dr. Bamgbose coordinated the paper writing and review and provided administrative support; Dr. Adeoye developed the methodology, acquired the data, and analyzed the result; Dr. Amole also supplied technical and material support.

\section{Acknowledgments}

The authors are grateful to the staff of the Maxillofacial Surgery Center of the Aminu Kano Teaching Hospital who delivered the self-administered questionnaires to the traditional healers and herbalists. They are also grateful to all the traditional healthcare providers who enrolled in the study.

\section{References}

[1] N. W. Johnson, S. Warnakulasuriya, P. C. Gupta et al., "Global oral health inequalities in incidence and outcomes for oral cancer: causes and solutions," Advances in Dental Research, vol. 23, no. 2, pp. 237-246, 2011.

[2] S. N. Rogers, R. Pabla, A. McSorley, D. Lowe, J. S. Brown, and E. D. Vaughan, "An assessment of deprivation as a factor in the delays in presentation, diagnosis and treatment in patients with oral and oropharyngeal squamous cell carcinoma," Oral Oncology, vol. 43, no. 7, pp. 648-655, 2007.

[3] S. N. Rogers, J. S. Brown, J. A. Woolgar et al., "Survival following primary surgery for oral cancer," Oral Oncology, vol. 45, no. 3, pp. 201-211, 2009.

[4] L. A. G. Ries, C. L. Kosary, B. F. Hankey, B. A. Miller, L. Clegg, and B. K. Edwards, SEERS Cancer Statistics Review, 1973-1996, National Cancer Institute, Bethseda, Mass, USA, 1999.

[5] J. A. Yellowitz and H. S. Goodman, "Assessing physicians' and dentists' oral cancer knowledge, opinions and practices," The Journal of the American Dental Association, vol. 126, no. 1, pp. 53-60, 1995.

[6] R. T. Greenlee, M. B. Hill-Harmon, T. Murray, and M. Thun, "Cancer statistics, 2001," Ca: A Cancer Journal for Clinicians, vol. 51, no. 1, pp. 15-36, 2001.

[7] E. O. Adekeye, E. Asamoa, and B. Cohen, "Intraoral carcinoma in Nigeria: a review of 137 cases," Annals of the Royal College of Surgeons of England, vol. 67, no. 3, pp. 180-182, 1985.

[8] M. M. Chidzonga and L. Mahomva, "Squamous cell carcinoma of the oral cavity, maxillary antrum and lip in a Zimbabwean population: a descriptive epidemiological study," Oral Oncology, vol. 42, no. 2, pp. 184-189, 2006.

[9] M. M. Chidzonga, "Oral malignant neoplasia: a survey of 428 cases in two Zimbabwean hospitals," Oral Oncology, vol. 42, no. 2, pp. 177-183, 2006.

[10] J. N. Davies and B. A. Wilson, "Cancer in Kampala, 1952-1953," East African Medical Journal, vol. 31, no. 9, pp. 395-416, 1954.

[11] B. F. Adeyemi, B. M. Kolude, and E. E. Akang, "A retrospective histopathological review of oral squamous cell carcinoma in a Nigerian teaching hospital," African Journal of Medicine and Medical Sciences, vol. 40, no. 2, pp. 153-158, 2011.

[12] A. O. Lawal, B. M. Kolude, and B. F. Adeyemi, "Oral cancer: the Nigerian experience," International Journal of Medical Sciences, vol. 5, no. 4, pp. 178-183, 2013.

[13] B. F. Adeyemi, L. V. Adekunle, B. M. Kolude, E. E. U. Akang, and J. O. Lawoyin, "Head and neck cancer-a clinicopathological study in a tertiary care center," Journal of the National Medical Association, vol. 100, no. 6, pp. 690-697, 2008.

[14] J. T. Arotiba, A. E. Obiechina, O. A. Fasola, O. I. Fawole, and H. A. Ajagbe, "Oral squamous cell carcinoma: a review of 246 Nigerian cases," African Journal of Medicine and Medical Sciences, vol. 28, no. 3-4, pp. 141-144, 1999.

[15] J. O. Daramola, H. A. Ajagbe, and J. O. Oluwasanmi, "Pattern of oral cancer in a Nigerian population," British Journal of Oral Surgery, vol. 17, no. 2, pp. 123-128, 1979.

[16] G. T. Arotiba, A. L. Ladeinde, J. O. Oyeneyin, C. C. Nwawolo, A. A. F. Banjo, and O. F. Ajayi, "Malignant orofacial neoplasms in 
Lagos, Nigeria," East African Medical Journal, vol. 83, no. 3, pp. 62-68, 2006.

[17] O. A. Effiom, W. L. Adeyemo, O. G. Omitola, O. F. Ajayi, M. M. Emmanuel, and O. M. Gbotolorun, "Oral squamous cell carcinoma: a clinicopathologic review of 233 cases in Lagos, Nigeria," Journal of Oral and Maxillofacial Surgery, vol. 66, no. 8, pp. 1595-1599, 2008.

[18] O. F. Ajayi, W. L. Adeyemo, A. L. Ladeinde et al., "Primary malignant neoplasms of orofacial origin: a retrospective review of 256 cases in a Nigerian tertiary hospital," International Journal of Oral and Maxillofacial Surgery, vol. 36, no. 5, pp. 403-408, 2007.

[19] C. Oji and F. N. Chukwuneke, "Oral cancer in Enugu, Nigeria, 1998-2003," British Journal of Oral and Maxillofacial Surgery, vol. 45, no. 4, pp. 298-301, 2007.

[20] E. C. Otoh, N. W. Johnson, H. O. Olasoji, I. S. Danfillo, and O. A. Adeleke, "Intra-oral carcinomas in Maiduguri, north-eastern Nigeria," Oral Diseases, vol. 11, no. 6, pp. 379-385, 2005.

[21] E. C. Otoh, N. W. Johnson, H. Olasoji, I. S. Danfillo, and O. A. Adeleke, "Salivary gland neoplasms in Maiduguri, northeastern Nigeria," Oral Diseases, vol. 11, no. 6, pp. 386-391, 2005.

[22] E. C. Otoh, N. W. Johnson, B. M. Mandong, and I. S. Danfillo, "Pattern of oral cancers in the North central zone of Nigeria," African Journal of Oral Health, vol. 1, pp. 47-53, 2004.

[23] http://www.corporate-nigeria.com/index/industry/beerindustry.html.

[24] E. Dumbili, "Changing patterns of alcohol consumption in Nigeria: an exploration of responsible factors and consequences," Medical Sociology Online, vol. 7, no. 1, pp. 20-33, 2013.

[25] http://www.pbs.org/newshour/bb/africa/nigeria/sharia_law. html.

[26] World Health Organization, "Global Status Report on Alcohol 2004," http://www.who.int/substance_abuse/publications/en/ nigeria.pdf.

[27] World Health Organization, "Global Adult Tobacco Survey (Nigeria): country report 2012," http://www.who.int/substance_ abuse/publications/en/nigeria.pdf.

[28] I. S. Obot, "The use of tobacco products among Nigerian adults: a general population survey," Drug and Alcohol Dependence, vol. 26, no. 2, pp. 203-208, 1990.

[29] Center for disease control, "Risk factors for Oral Cancer," http:// www.oralcancerfoundation.org/cdc/cdc_chapter3.htm.

[30] http://en.wikipedia.org/wiki/Kano.

[31] L. A. G. Ries, M. P. Eisner, C. L. Kosary et al., SEER Cancer Statistics Review, 1975-2002, National Cancer Institute, Bethseda, Md, USA, 2005.

[32] Centers for Disease Control and Prevention, "Preventing and controlling oral and pharyngeal cancer. Recommendations from a national strategic planning conference," $M M W R$, vol. 47, no. RR-14, pp. 1-12, 1998.

[33] http://www.population.gov.ng/index.php/censuses.

[34] http://nigeria.unfpa.org/kano.html.

[35] R. King, D. Balaba, B. Kaboru, D. Kabatesi, A. Pharris, and H. Jaco, "The role of traditional healers in comprehensive HIV/ AIDS prevention and care in Africa: untapped Opportunities," http://ftguonline.org/.

[36] K. Sorsdahl, D. J. Stein, and A. J. Flisher, "Predicting referral practices of traditional healers of their patients with a mental illness: an application of the theory of planned behaviour," African Journal of Psychiatry, vol. 16, no. 1, pp. 35-40, 2013.
[37] S. J. Arbes Jr., A. F. Olshan, D. J. Caplan, V. J. Schoenbach, G. D. Slade, and M. J. Symons, "Factors contributing to the poorer survival of black Americans diagnosed with oral cancer (United States)," Cancer Causes and Control, vol. 10, no. 6, pp. 513-523, 1999.

[38] V. L. Shavers, L. C. Harlan, D. Winn, and W. W. Davis, "Racial/ ethnic patterns of care for cancers of the oral cavity, pharynx, larynx, sinuses, and salivary glands," Cancer and Metastasis Reviews, vol. 22, no. 1, pp. 25-38, 2003.

[39] S. L. Tomar, M. Loree, and H. Logan, "Racial differences in oral and pharyngeal cancer treatment and survival in Florida," Cancer Causes and Control, vol. 15, no. 6, pp. 601-609, 2004.

[40] D. J. Caplan and I. Hertz-Picciotto, "Racial differences in survival of oral and pharyngeal cancer patients in North Carolina," Journal of Public Health Dentistry, vol. 58, no. 1, pp. 36-43, 1998.

[41] C. A. Winters, "Koranic education and militant Islam in Nigeria," International Review of Education, vol. 33, no. 2, pp. 171-185, 1987.

[42] P. Andre and J. L. Demonsant, "Koranic Schools in Senegal: a real barrier to formal education?" 2009, http://www.parisschoolofeconomics.eu/.

[43] N. M. Baba, "Between the State and the Malam: understanding the forces that shape the future of Nigerias Quranic Schools," Journal of Law, Religion and State, vol. 1, no. 2, pp. 97-116, 2012.

[44] J. A. Yellowitz, A. M. Horowitz, T. F. Drury, and H. S. Goodman, "Survey of U.S. dentists' knowledge and opinions about oral pharyngeal cancer," Journal of the American Dental Association, vol. 131, no. 5, pp. 653-661, 2000.

[45] C. H. Shiboski, S. C. Shiboski, and S. Silverman Jr., "Trends in oral cancer rates in the United States, 1973-1996," Community Dentistry and Oral Epidemiology, vol. 28, no. 4, pp. 249-256, 2000.

[46] P. A. Swango, "Cancers of the oral cavity and pharynx in the United States: an epidemiologic overview," Journal of Public Health Dentistry, vol. 56, no. 6, pp. 309-318, 1996.

[47] J. O. Lawoyin, G. A. Aderinokun, B. Kolude, S. M. Adekoya, and O. T. Ogundipe, "Oral cancer awareness and prevalence of risk behaviours among dental patients in South-western Nigeria," African Journal of Medicine and Medical Sciences, vol. 32, no. 2, pp. 203-207, 2003.

[48] L. L. Patton, R. Agans, J. R. Elter, J. H. Southerland, R. P. Strauss, and W. D. Kalsbeek, "Oral cancer knowledge and examination experiences among North Carolina adults," Journal of Public Health Dentistry, vol. 64, no. 3, pp. 173-180, 2004. 


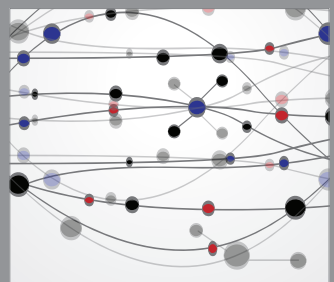

The Scientific World Journal
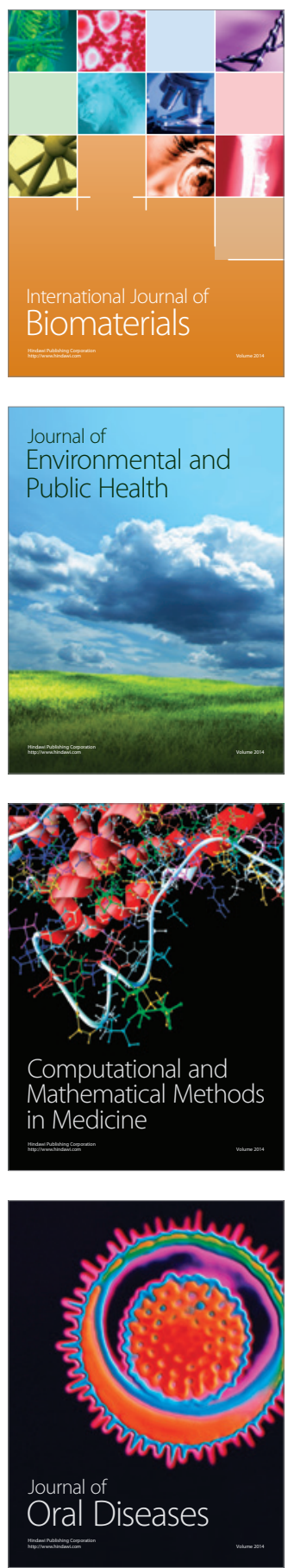
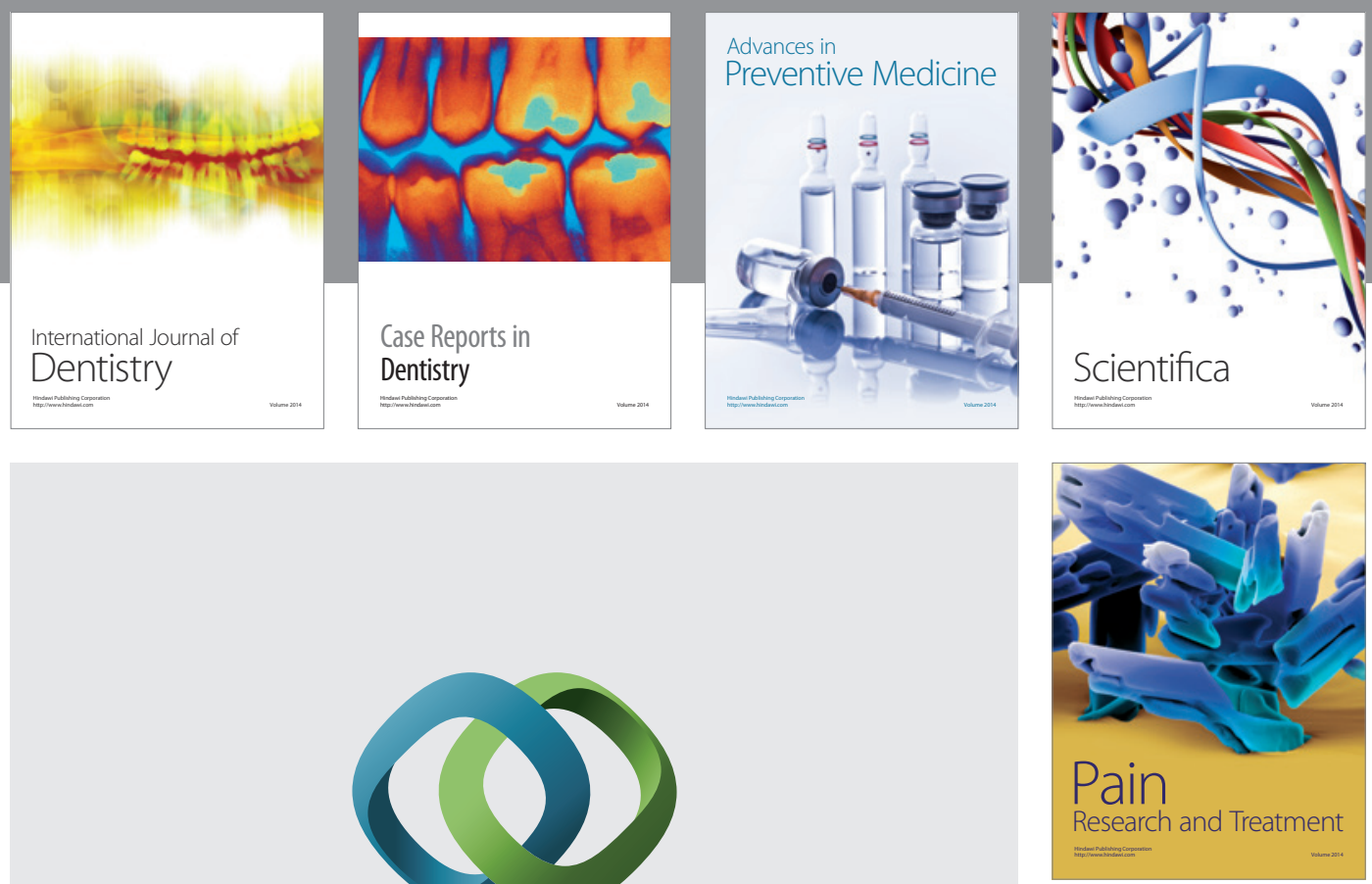

\section{Hindawi}

Submit your manuscripts at

http://www.hindawi.com
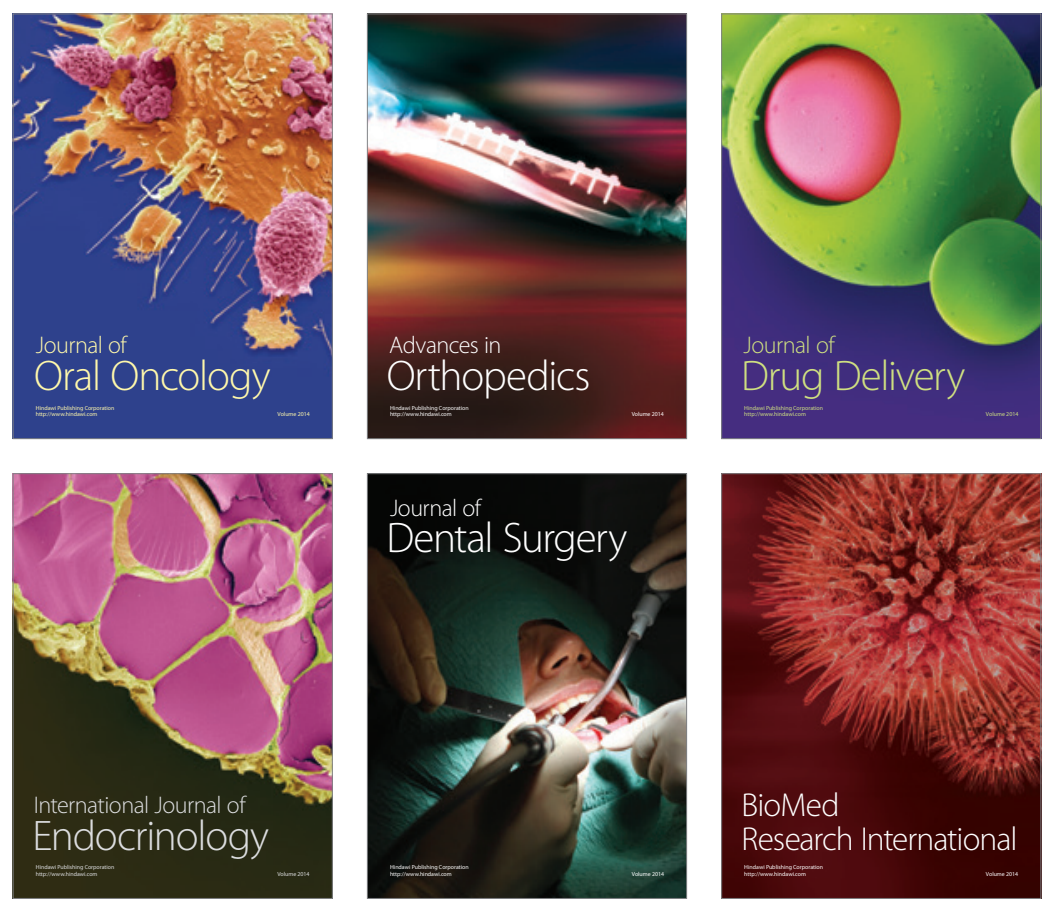

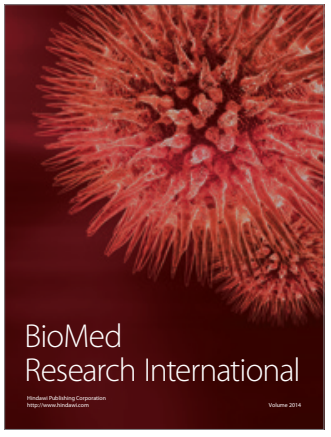

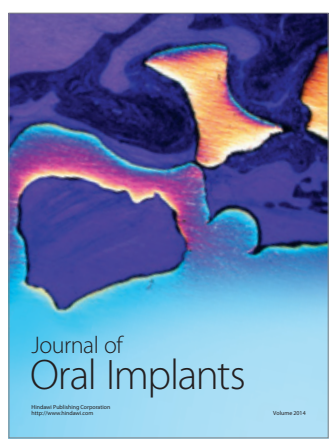
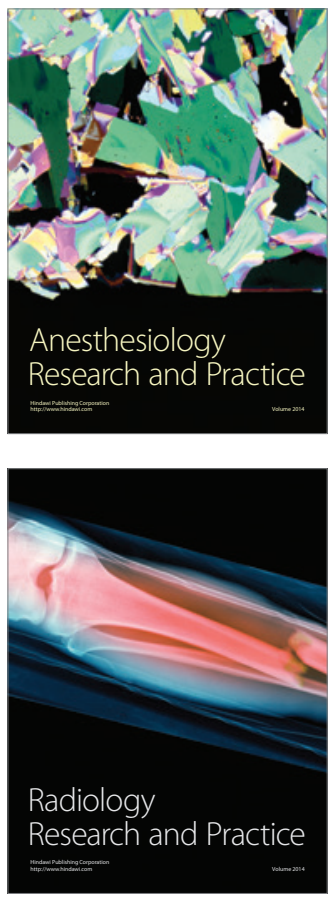